Ritrýnd grein birt 28. mars 2019

\title{
Eftirsóttasti minnihlutahópurinn? Fyrstu mánuðir fjögurra karla í grunnskólakennslu
}

\author{
Andri Rafn Ottesen og Ingólfur Ásgeir Jóhannesson
}

$\checkmark$ Abstract Um höfundana About the authors $>$ Heimildir

Tilefni pessarar greinar er umræða um mögulegan kennaraskort í grunnskólum en einkum pó staða og fækkun kennslukarla í grunnskólum. Fræðilegur bakgrunnur hennar er annars vegar rannsóknir á leiðsögn við nýliða í starfi og hins vegar er sjónum beint að kennslukörlum í starfi. Sagt er frá rannsókn par sem ræett var við fjóra nýbrautskráða karla og peim fylgt eftir fyrstu sex mánuðina í starfi með premur viðtölum við hvern peirra skólaárið 2017-2018. Peir voru spurðir hvernig hefði gengið í starfinu að loknu námi og hvort peir hefðu upplifað einhverja pætti sem líklegt væri að tengdust pví að peir væru karlar. Meginrannsóknarspurningin var tvípætt: Hvernig gengur nýbrautskráðum körlum á vettvangi starfsins og purfa peir sérhæfðan stuðning í starfinu á grundvelli kyns síns? Í greininni er gerð grein fyrir premur pemum: Upplifun karlanna af nýjum starfsvettvangi og starfsumhverfinu par; reynslu peirra af leiðsögn við pá sem nýliða; og loks hvort og hvernig kyn og kyngervi birtast í frásögnum peirra. Viðmælendur okkar töldu að sér hefði gengið vel að fóta sig í starfi og peir voru ánægðir með leiðsögnina, pótt hún hefði ekki verið jafn formleg og mælt er með í fræðum og rannsóknum um leiðsögn. Svarið við spurningunni hvort pað purfi sérhæfðan stuðning eftir kyni er ekki einhlítt. Í svörum viðmælenda kom fram að í premur skólanna sem peir störfuðu hefðu verið karlaklúbbar sem peir töldu að hefðu verið sér gagnlegir við að aðlagast skólabragnum. Höfundar telja rétt að kanna hvort kynskiptir klúbbar gagnist í bví viðfangsefni að nýliðar haldist í starfinu. Mikilvægi markvissrar leiðsagnar fyrir nýliða í starfi er pó ekki kynbundið atriði heldur verður að leggja áherslu á að allir nýir kennarar, óháð kyni, fái góða leiðsögn pegar peir stíga sín fyrstu skref í starfi. Kynjaskipt leiðsögn væri pá einungis hluti af heildstæðu og vönduðu kerfi nýliðapjálfunar.

Efnisorð: Nýliðun, kennslukarlar, leiðsögn, kyn kennara, nýir kennarar.

\section{Inngangur}

Mögulegur kennaraskortur í grunnskólum landsins er áhyggjuefni. Hlutfall kennara með leyfisbréf til grunnskólakennslu breyttist lítið árin 2012-2016, var á bilinu 94-96\%, en lækkaði í 91,6\% haustið 2017 (Hagstofa Íslands, 2018). Einnig hafa Stefán Hrafn Jónsson og Helgi Eiríkur Eyjólfsson (2016) bent á með lýðfræðilegum útreikningum að líklegt sé að kennurum fækki á næstu áratugum og erfiðara verði að manna grunnskólana með menntuðum kennurum. Kynjahlutfall meðal grunnskólakennara er mjög ójafnt og fækkaði körlum um næstum átta prósentustig á árunum 1998-2017, samkvæmt tölum Hagstofunnar - úr 26\% í tæp 18\% (Hagstofa Íslands, e.d.-a). Í alpjóðlegri orðræðu er kveðið svo fast að orði að karlar í grunnskólum eigi á hættu að verða útdauða - ferlið sem felst í fækkun kennslukarlanna er kallað extinction (McGrath og Van Bergen, 
2017). „Útdauða“-orðræðan hefur sannarlega náð til Íslands pví að í riti Kennarasambands Íslands birtist 1 desember 2015 frásögn af úttekt hagfræðings samtakanna undir heitinu Eru karlar í kennarastétt að deyja út? (,Eru karlar“, 2015).

Lóð á vogarskálar pess að sporna við kennaraskorti er að styðja nýja kennara í starfi í upphafi (Ingersoll, 2012). Fyrstu skref kennara í grunnskólakennslu hér á landi hafa verið rannsökuð, til dæmis af Maríu Steingrímsdóttur (2007) sem athugaði reynslu og líðan átta nýbrautskráðra kennara á fyrsta starfsári og síðar eftir fimm fyrstu starfsárin (María Steingrímsdóttir, 2010) og Lilju M. Jónsdóttur (2012a, 2012b) um reynslu fimm byrjenda í grunnskólakennslu, líka um fimm ára skeið. Áherslan í pessum rannsóknum var lögð á að skoða starf peirra sem nýliða frekar en atriði sem lutu að kyni pátttakenda, og aðeins einn pátttakandi af prettán í pessum tveimur rannsóknum var karl.

Dessi grein er byggð á rannsókn par sem rætt var við fjóra nýbrautskráđa karla og peim fylgt eftir fyrstu sex mánuðina í starfi með premur viðtölum við hvern peirra skólaárið 2017-2018. Deir voru spurðir hvernig hefði gengið í starfinu að loknu námi og hvort peir hefðu upplifað einhverja pætti sem líklegt væri að tengdust pví að peir væru karlar. Meginrannsóknarspurningin var tvípætt: Hvernig gengur nýbrautskráđum körlum á vettvangi starfsins og purfa peir sérhæfðan stuðning í starfinu á grundvelli kyns síns? Fyrri hluti spurningarinnar var víðtækur að pví leyti að spurt var um kennsluna og um fagleg og félagsleg samskipti í skólanum, og sérstaklega um pá leiðsögn sem peir fengu.

Í niðurstöðunum er gerð grein fyrir premur af peim pemum sem fram komu: Upplifun kennslukarlanna af nýjum starfsvettvangi og starfsumhverfinu par; reynslu peirra af leiðsögn við pá sem nýliða; og loks hvort og hvernig kyn og kyngervi birtast í frásögnum peirra. [1]

\section{Bakgrunnur}

Bakgrunnur pessarar greinar er af tvennum toga: Annars vegar rannsóknir og kenningar um leiðsögn nýliða í kennslu; hins vegar kenningar um karlmennsku og rannsóknir á störfum og viðhorfum til kennslukarla.

\section{Kenningar og rannsóknir um leiðsögn nýliða}

Kennarastarf í grunnskólum er pess eðlis að pað verður ekki numið í eitt skipti fyrir öll í kennaranámi - og pað skiptir líklega ekki öllu máli hvort námið er prjú, fjögur eða fimm ár. Aðalmálið er að skólarnir purfa að hafa starfsumhverfi par sem nýliðar læra að kenna, ekki bara til pess að „lifa af“ (e. survive) fyrstu mánuðina eða misserin, sem pó er bráđnauðsynlegt til að ná árangri í starfinu (sjá til dæmis Estola, Syrjälä og Maunu, 2012; Hammerness, Darling-Hammond og Brandsford, 2005; Hoy og Spero, 2005; Ingersoll, 2012; Lilja M. Jónsdóttur, 2012a, 2012b; María Steingrímsdóttur, 2007, 2010). Margar rannsóknir benda til pess að nýir kennarar purfi prjú til fjögur ár til að öðlast hæfni (e. competence) í kennarastarfinu og enn fleiri ár til að ná afburðahæfni (e. expertise) (Berliner, 1992; Hammerness o.fl., 2005).

Estola og félagar (2012) komust að pví að nýir kennarar virðast allir mæta svipuðum áskorunum. Dær felast í pví að finna jafnvægi milli vinnuálags og starfsánægju og skapa sér tíma til að ræða við samstarfsfólk, nemendur og foreldra. Nýliða skortir einnig hið starfstengda innsæi sem reyndari kennarar eru gjarna búnir að temja sér (Sternberg og Horvath, 1995) og nýliðar eiga einnig til að vanmeta hversu flókið starfið getur verið (Hoy og Spero, 2005). Óreyndur kennari bregst öđruvísi við heldur en sá reyndari og pví er viðfangsefni eins og foreldrasamskipti skýrt dæmi um muninn á reyndum og óreyndum kennara. Samskipti við foreldra eru meðal peirra atriða sem hafa reynst nýliðum fyrirkvíðanlegra viðfangsefni en mörg önnur (Lilja M. Jónsdóttir, 2012b; María Steingrímsdóttir, 2007). 
Vísbendingar eru um að ef nýir kennarar fái litla aðstoð muni peir halda áfram að kenna með minni hæfni en ella. Mikil hætta er pá talin á að álag í starfi verði peim ofviða og geti jafnvel leitt til pess að peir yfirgefi starfið eftir stuttan tíma (Hammerness o.fl., 2005; Ingersoll, 2012; María Steingrímsdóttur, 2007). Til dæmis höfðu 27\% af 239 svarendum í rannsókn Maríu Steingrímsdóttur og Guðmundar Engilbertssonar (2018) hugleitt að hætta einhvern tíma á fyrstu premur starfsárunum í kennslu í grunn- eða framhaldsskóla á Íslandi.

Meðal peirra leiða sem skólar hafa til að styrkja nýliða í starfi er leiðsögn (e. mentoring) við nýliðann. Enda pótt leiðsögn sé í daglegu tali ekki afmarkað fyrirbæri, og geti átt við um margt, vísar leiðsagnarhugtak í pessu samhengi til formlegs ferlis par sem reyndur kennari veitir reynsluminni kennara, nýliða, eða kennaranema leiðsögn (Le Cornu, 2005; María Steingrímsdóttir, Eygló Björnsdóttir og Gretar L. Marinósson, 2018; Ragnhildur Bjarnadóttir, 2015). Slíkt samstarf milli reynslumikils og reynslulítils kennara er hugsað sem stuðningur fyrir pann reynsluminni en pað getur engu að síður gagnast peim reynslumeiri par sem hann getur líka lært af nýliðanum (Hargreaves og Fullan, 2000). María Steingrímsdóttir (2007) bendir á að skólasamfélagið purfi að viðurkenna að nýliðar komi ekki fullnuma úr kennaranáminu. Samkvæmt nýlegri skýrslu Efnahags- og framfarastofnunarinnar (OECD) er petta viðurkennt í flestum löndum sem taka pátt í samstarfi hennar með pví að viðhaft er sérstakt skipulag við móttöku nýliða (e. induction) (Jensen, Sandoval-Hernández, Knoll og Gonzales, 2012). María Steingrímsdóttir og Guðmundur Engilbertsson (2018) leggja einnig áherslu á að móttaka og leiðsögn nýrra kennara purfi að vera markvissari en tíðkast hefur, bæði í gegnum val á leiðsagnarkennara (e. mentor, tutor, supervisor) og með skipulegum fundum hans með nýliðunum.

Umfangsmestu rannsóknir á starfi nýbrautskráðra grunnskólakennara hér á landi hafa verið gerðar af Lilju M. Jónsdóttur, Maríu Steingrímsdóttur og Guðmundi Engilbertssyni. Lilja M. Jónsdóttir (2012a, 2012b) fylgdi eftir fimm nýbrautskráđum grunnskólakennurum, fjórum konum og einum karli, á árunum 2002-2007, í peim tilgangi að varpa ljósi á hvernig peir næðu tökum á starfi sínu og hvernig peir próuðust sem byrjendur; hvað hindraði og hvað styddi pá. Einnig var athugað hvers konar leiðsögn nýliðar í kennslu pyrftu á að halda fyrstu árin í kennslu. Rætt var við hvern og einn pátttakanda rétt áđur en hann eða hún hóf kennslu í fyrsta sinn og svo tvisvar á fyrsta kennsluárinu, næst í lok annars og priðja kennsluársins og loks var rætt við pátttakendur í lok pess fimmta. Pátttakendur í rannsókn Lilju héldu pví meðal annars fram að pað vantaði meiri hagnýta kennslufræði í námið en einnig kennslu í að vinna með mál tengd erfiðum nemendum og nemendum með sérparfir (Lilja M. Jónsdóttir, 2012a). Meðal ályktana Lilju var að veita pyrfti byrjendum í kennslu mun meiri stuðning en í boði hefur verið hér á landi og í töluvert lengri tíma en petta fyrsta ár í kennslu, sem hefur tíðkast hingað til.

María Steingrímsdóttir fylgdi eftir nýbrautskráđum grunnskólakennurum, átta konum sem brautskráđust með B.Ed.-gráđu frá Kennaraháskóla Íslands og kennaradeild Háskólans á Akureyri vorið 2003. Hún tók prjú viðtöl við pær á fyrsta starfsári, skólaárið 2003-2004 (María Steingrímsdóttir, 2007) og eitt vorið 2008 (María Steingrímsdóttir, 2010). Niðurstöður Maríu benda til pess að ekki sé aðeins pörf fyrir stuðning á fyrsta starfsári; reynsla kennslukvennanna, sem hún talaði við, gefur til kynna að pær hafi verið að aðlagast starfsvettvanginum fyrstu tvö starfsárin og að pær hefðu purft meiri stuðning en peim stóð til boða (María Steingrímsdóttir, 2010).

María Steingrímsdóttir og Guðmundur Engilbertsson $(2014,2018)$ fengu svör við spurningalista frá 239 kennurum á 1.-3. starfsári í kennslu í grunn- og framhaldsskólum. Í ljós kom að peir sem fengu formlega leiðsögn, til dæmis í formi skipulegra og nokkuð tíðra funda, töldu hana nýtast betur en peir sem fengu eingöngu óformlega leiðsögn eða purftu að leita eftir henni. Einnig töldu peir kennarar sem fengu leiðsögn, frá peim sem pekktu kennslugreinina, að sú leiðsögn hefði nýst betur. 
Vönduð leiðsögn snýst ekki um að uppfylla formsatriði (Jensen o.fl., 2012) heldur er starfið ígrundað með nýliðunum, peim hrósað fyrir pað sem vel er gert og peim leiðbeint á uppbyggilegan hátt um pað sem betur mætti fara. Rannsóknir gefa til kynna að leiðsögn við nýliða sé afar mikilvæg en pað er engu síður mikilvægt hvernig að henni er staðið.

\section{Karlmennska og rannsóknir á störfum og viðhorfum til kennslukarla}

Degar kynjahlutföll í starfi eru orðin pau að nær tveir priðju eða meira af fjölda í starfinu tilheyra öðru kyninu er stundum litið pannig á að starfið sé karla- eða kvennastarf (Ingólfur Ásgeir Jóhannesson, 2004; Nefnd um efnahagsleg völd kvenna, 2004). Í tilviki grunnskólakennara eru kynjahlutföllin orðin enn öfgafyllri pótt starfið hafi verið jafnt karla- og kvennastarf fyrir örfáum áratugum hér á landi. Hugmyndin um karlastörf og kvennastörf er pó byggð á fjöldatölum en ekki pví að eðlis og saga starfsins sé kvenlæg eða karllæg. Út frá sögulegu sjónarhorni var starf grunnskólakennara ekki starf annars hvors kynsins og jafnvel frekar karla en kvenna; karlar voru til dæmis 60\% kennara í Reykjavík frá pví um 1930 til 1960 (Loftur Guttormsson og Ólöf Garðarsdóttir, 2012). Konum fjölgaði mjög mikið í starfinu á síðustu áratugum 20. aldar meðan fjöldi karla hélst óbreyttur eða peim fækkaði. Hlutföllin héldu síðan áfram að verða körlum í óhag eftir aldamótin.

Í opinberri umræðu ber talsvert á peirri eðlishyggju að ætla störfum eiginleika sem henti annað hvort körlum eða konum sérstaklega. Einnig ber á slíkri orðræðu meðal foreldra (Maríanna Jónsdóttir Maríudóttir og Ingólfur Ásgeir Jóhannesson, 2018). Með eðlishyggjunni eru körlum og konum ætlaðir vissir eiginleikar, sem nefndir eru karlmennska og kvenleiki. Hugtakið karlmennska hefur verið tengt við að karlar séu agaðri, harðari af sér, rökvísari, hlutlægari og sneggri að bregðast við vanda meðan kvenleikinn einkennist af umhyggju en jafnframt veiklyndi (sjá til dæmis Connell og Messerschmidt, 2005; Ingólf Ásgeir Jóhannesson, 2004). Í alpjóðlegum fræðum ber mikið á gagnrýni á pá útbreiddu hugmynd að kennslukarlar eigi að pjóna sem fyrirmyndir fyrir drengina, sérstaklega vegna pess að sú krafa hefur pótt beinast að pví að peir sýndu af sér tiltölulega hefðbundna karlmennsku (sjá til dæmis Francis, 2008; Hjalmarsson og Löfdahl, 2014). Ennfremur æetti að horfa til pess að fá karla til pess að endurskilgreina hvað karlmennska er (Martino, 2008).

Ekki er hægt að fullyrða að pað sé vegna slíkra hugmynda um karlmennsku og kvenleika að karlar sækjast enn síður eftir pví að starfa með yngstu börnunum en með eldri börnum. Dannig eru kynjahlutföll frekar jöfn í framhaldsskólakennslu hér á landi miðað við síðustu tölur Hagstofu Íslands (e.d.-b) pótt konum hafi fjölgað hlutfallslega og orðið fleiri frá og með haustinu 2005. Í leikskólastarfinu var hlutfall karla tæp 6\% haustið 2016 (Hagstofa Íslands, e.d.-c). Einnig eru færri karlar sem sækjast eftir störfum á yngri stigum grunnskólans. Tölur Hagstofu Íslands sundurgreina pó ekki kyn kennara eftir aldursstigi grunnskóla pannig að ekki er hægt að gefa upp tölur um mun á hlutfalli karla í til dæmis 1.-4. bekk miðað við eldri stigin. Höfundar greinarinnar könnuðu heimasíður priggja safnskóla í Reykjavík og Garðabæ par sem eingöngu er kennt í 8.-10. bekk; karlarnir reyndust tæp 37\% kennaranna í pessum skólum en aðeins rúm 11\% kennaranna í sjö skólum sem leggja safnskólunum premur til nemendur. [2]

Eðlishyggjan endurómast í svörum 14 kennslukvenna sem Ingólfur Ásgeir Jóhannesson (2004) spurði hvort pær teldu að munur væri á störfum kennslukvenna og -karla. Pótt pær hefðu talið mun milli kennara frekar vera einstaklingsbundinn en kynjabundinn, kom engu að síður fram margvíslegur kynjaður munur í svörum peirra. Til að mynda töldu pær að kennslukarlarnir hleyptu nemendum sínum ekki eins nálægt sér og kennslukonur gera. Karlar sæktu síður í kennslu á yngsta stigi, eflaust vegna pess að peir væru ekki eins tilbúnir að taka að sér móðurhlutverkið eins og konur. Sambærilegt álit kemur fram í nýlegri rannsókn um viðhorf foreldra til kyns og kyngervis grunnskólakennara (Maríanna Jónsdóttir Maríudóttir og Ingólfur Ásgeir Jóhannesson, 2018). 
Tilhneigingin að karlar vinni síður með yngstu börnunum er alpjóðlegt fyrirbæri. Bhana og Moosa (2016) rannsökuðu ástæður pess að karlar í Suður-Afríku fengust ekki til að vinna við kennslu í leikskólum. Deir karlar sem Bhana og Moosa ræddu við, sem kenna yngri börnum, töldu að karlar veldu frekar að kenna eldri nemendum par sem pað hentaði peim betur, bæði vegna meiri vitsmunalegri getu eldri nemenda og hærri samfélagslegrar stöðu, par sem litið sé til pess að kennsla yngri barna sé meira og minna umönnunarstarf. Meirihluti karlanna leit svo á að störfin hentuðu konum betur ásamt pví að pær byggju yfir peirri hæfni sem pyrfti til að sinna starfinu. Deir óttuðust einnig að samfélagið gerði lítið úr peim og karlmennsku peirra ef peir færu að kenna yngri börnum. Cushman (2005) ræddi við 17 kennslukarla á Nýja-Sjálandi sem höfðu áhyggjur af pjóðfélagslegu mati á starfi kennara, en peir eldri í hópnum töldu pað hafa lækkað. Deir kvörtuðu undan laununum og pví að vinna í kvenlægu umhverfi par sem væru fáir aðrir karlar. Vinna í kvenlægu umhverfi var einnig áhyggjuefni 35 karla sem kenna á yngsta stigi grunnskóla í suðurhluta Kaliforníu, sem Sargent (2001) tók viðtöl við. Deir virtust allir átta sig á pví að peir tilheyrðu minnihluta og pyrftu að aðlaga sig að peim aðstæðum. Nokkrum viðmælendum Sargents fannst umhverfið á kennarastofunni vera full kvenlægt og peir hefðu lítið að bjóða í samræðum, til dæmis um túrverki, hitaköst og fæðingar. Tveir af viðmælendum Sargents sögðu frá pví að peir borðuðu nesti sitt stundum í kennslustofunni frekar en á kennarastofunni til að losna við skammir frá samkennurum sínum. Dar vitnuðu peir í kennslukonur sem virtust yfirfæra pirring gagnvart eiginmönnum sínum á pá og alhæfa pannig að allir karlar væru fífl.

Hugmyndir íslenskra kennslukarla hafa ekki verið mikið rannsakaðar með hliðsjón af hugmyndum um kyngervi. Í rannsóknum um nýliðun í starfi grunnskólakennara hefur sjónum heldur ekki verið beint sérstaklega að mögulegum áhrifum kyns og kyngervis í starfinu. Tímabært er pví að rannsaka hugmyndir kennslukarla í pessu ljósi.

\section{Аðferð}

\section{Pátttakendur}

Rannsóknin, sem greinin byggist á, var viðtalsrannsókn par sem rætt var við fjóra nýbrautskráða karla, prívegis hvern, á fyrstu sex mánuðum peirra í starfi. Viðmælendur í rannsókninni áttu að uppfylla prjú skilyrði til að geta orðið pátttakendur í rannsókninni. Í fyrsta lagi purftu peir að vera karlkyns, í öðru lagi að hafa brautskráðst úr kennaranámi vorið 2017 og hafa hafið störf við kennslu í grunnskóla sama haust og í priðja lagi að hafa helst ekki starfað sem leiðbeinendur fyrir útskrift. Peir sem uppfylltu pessi skilyrði mynduðu pýðið.

Val á viðmælendum fór fram með peim hætti að tveir pátttakendur voru valdir gegnum kunningjatengsl við fyrri höfund greinar en hinir tveir lýstu áhuga á pátttöku í rannsókninni eftir að póstur hafði verið sendur frá deildarskrifstofu Kennaradeildar Háskóla Íslands til priggja einstaklinga í brautskráningarhópnum. Allir fjórir viðmælendurnir brautskráđust úr Kennaradeild Háskóla Íslands vorið 2017. Einnig var leitað til Kennaradeildar Háskólans á Akureyri eftir pátttakendum en enginn í brautskráningarhópnum par reyndist uppfylla skilyrðin. Ekki var leitað til Listkennsludeildar Listaháskóla Íslands að pessu sinni.

Viðmælendur í rannsókninni fengu dulnefnin Egill, Gunnar, Nói og Viktor. Deir Egill og Gunnar voru undir prítugu en Nói og Viktor milli prítugs og fertugs. Peir yngri voru báđir umsjónarkennarar, Egill á miðstigi en Gunnar á unglingastigi. Deir eldri voru báđir faggreinakennarar. Egill kenndi í grunnskóla á Norðurlandi, Nói í grunnskóla á Vesturlandi og peir Gunnar og Viktor í grunnskólum á höfuðborgarsvæðinu. Einn pátttakendanna, Viktor, hafði kennt sem leiðbeinandi samhliða námi sínu en ákveðið var að afturkalla ekki beiðnina um viðtölin enda var hann byrjaður í nýju starfi sem síðan átti eftir að endurspeglast í viðtölunum sjálfum. 


\section{Gagnaöflun og greining}

Rannsóknin er sem fyrr segir viðtalsrannsókn og var aðferðum eigindlegra rannsókna beitt. Fyrri höfundur tók prjú viðtöl við hvern viðmælanda, svo í heildina urðu viðtölin tólf. Fyrstu viðtölin fóru fram á tímabilinu 1.-19. ágúst, viðtöl í annarri umferð fóru fram á tímabilinu 30. október til 20. nóvember, og í priðju umferð á tímabilinu 25. janúar til 2. febrúar. [3] Fyrstu viðtölin fóru fram utan skólanna en síðari viðtölin ýmist í gegnum Skype, í skólunum eða utan skólans. Viðtölin voru hljóðrituð og afrituð orðrétt.

Spurningaramminn, sem notaður var í viðtölunum, var saminn áður en viðtöl voru tekin og sömdu höfundar spurningarnar í samvinnu. Dær voru hálfopnar og gaf pað viðmælendum tækifæri til að tjá sig og koma sínum athugasemdum á framfæri. Fyrir fyrstu viðtölin voru spurningarnar samdar með раð í huga að kynnast viðmælendum betur og heyra hvernig peir undirbjuggu sig fyrir starfið. Spurningarammi fyrir viðtal tvö miðaði að pví að heyra hvernig fyrstu skrefin í kennslu hefðu gengið og hvað hefði komið á óvart og loks voru spurningar í priðju umferðinni miðaðar að pví að draga saman reynslu viðmælenda af fyrstu sex mánuðunum í starfi.

Gagnaöflun og greining viðtalanna fór fram jafnóðum. Degar fyrri höfundur hafði tekið öll viðtöl í fyrstu umferð og unnið að frumgreiningu gagnanna ræddu höfundarnir saman um pau svör sem voru komin. Í kjölfarið lögðu peir línurnar fyrir næstu umferð. Sama fyrirkomulag var á vinnunni eftir að öllum viðtölum í annarri umferð lauk. Að loknum síðustu viðtölunum voru öll viðtölin paullesin og efni peirra flokkað. Við úrvinnsluna leituðu rannsakendur að pemum í svörum viðmælenda. Leitað var að pví sem viðmælendur voru sammála eða ósammála um og einnig að áhugaverðum atriðum úr reynslu hvers og eins. Að pví loknu var skrifuð frásögn, sem í pessari grein er skipt í prjá kafla sem innihalda eitt meginpema hver og nokkur undirpemu. Á lokaprepi rannsóknarinnar var svo leitast við að svara hinni tvípættu rannsóknarspurningu.

\section{Gildi rannsóknar og siðferðilegir pættir}

Markmið með viðtölunum var að safna gögnum sem veittu innsýn í fyrstu mánuði nýbrautskráðra kennara. Fjórir viðmælendur er tiltölulega hátt hlutfall af peim körlum sem brautskrást árlega en engu að síður eru viðmælendur fáir, en prjú viðtöl við hvern og einn með nokkru millibili reyndust gefa betri sýn en líklegt er að eitt eða tvö hefðu gert, par sem pau buðu upp á mat á próun á ákveðnum tíma. Frásagnir viðmælenda gefa góða mynd af reynslu peirra sem karla í upphafi starfs síns sem kennarar, en vitaskuld er ekki hægt að alhæfa um reynslu allra nýbrautskráðra karla út frá peim.

Í rannsókninni hefur verið gætt að nafnleynd og að persónulegar upplýsingar um viðmælendur komi hvergi fram. Engir nema rannsakendurnir vita hverjir pátttakendurnir voru og peir vissu ekki hver af öðrum að öðru leyti en pví að rætt væri við fleiri pátttakendur. Að lokinni rannsókn var hljóðupptökum eytt.

\section{Niðurstöður}

Niðurstöðum er skipt í prjá kafla sem fjalla um nýjan starfsvettvang, leiðsögnina sem viðmælendur fengu og hvernig kyn kennara birtist í frásögnum peirra.

\section{Nýr starfsvettvangur}

Viðmælendurnir völdu kennarastarfið af sömu ástæðunni, peirri að peir vildu vinna með fólki í lifandi og skemmtilegu umhverfi. Egill minntist á að enginn dagur væri eins og pað væri spennandi, Gunnar talaði um fjölbreytnina meðal nemenda og Viktor og Nói tóku fram að starfið hentaði vel með ípróttapjálfun sem aukastarfi. Viðmælendur voru sammála um að fyrstu 
mánuðirnir í starfinu hefðu gengið vel, auðvelt hefði verið að kynnast nemendum og komast inn í skólabraginn. Pó allt hefði á heildina litið gengið vel purftu viðmælendur samt að prófa sig áfram:

Dað sem mér fannst örugglega ganga best voru ákveðnar aðferðir og hugmyndafræði sem ég var að prófa mig áfram í ... mér hefur fundist mér ganga vel að komast svona inn í skólastarfið og menninguna og nemendahópinn. (Gunnar, viðtal I.3)

Viðmælendur sögðust finna fyrir talsverðu vinnuálagi og töldu að pað mætti rekja til reynsluleysis. Deir fundu fyrir mikilli ábyrgð og vinnudagarnir hefðu stundum verið langir. Vinnuálagið var meira en peir höfðu búist við og starfið krefjandi og tæki á en á sama tíma væri pað skemmtilegt og fjölbreytilegt. Pannig virtist vinnuálagið engan veginn draga úr peim kjarkinn:

Jú, petta er hellings vinnuálag og svona en petta er bara svo mikið ... allir fundir, allt skipulag, fyrsta árið fór bara í að komast inn í allt og fyrir utan pað er svo margt í starfsmannahópnum líka ... (Nói, viðtal I.2)

Samdóma álit viðmælenda, og pað sem stóð upp úr í upphafi kennslunnar, var að kynnast nemendum sínum. Deir hefðu nád auðveldlega til nemendanna og verið fljótir að mynda góð tengsl við pá. Á hinn bóginn voru samskipti við foreldra pað sem peim fannst peir síst tilbúnir fyrir, og hefði jafnvel valdið peim kvíða:

Dú getur lent í pví að vera með skemmtilegan hóp sem gerir petta auðvelt en svo getur pú líka lent í rosalega erfiðum nemendahópi og foreldrahópum sem gerir petta ótrúlega erfitt og pá langar mann að hætta. Erfið foreldrasamskipti eru pannig að pá langar manni bara að hætta ... (Nói, viðtal I.2)

Nýi starfsvettvangurinn var spennandi í augum viðmælendanna. Nú fengu peir að kynnast starfi kennarans betur með hverjum deginum og gátu fundið helstu kosti og galla sem pví fylgdi. Kostir starfsins í augum viðmælendanna sneru að pví hvað starfið var gefandi og skemmtilegt ásamt peim fjölbreytileika sem býðst. Nemendurnir voru einnig stór páttur í að glæða starfið peirri gleði sem peir fundu. Degar viðmælendur veltu fyrir sér göllum starfsins var ekki eins margt sem peir gátu talið upp. Deir nefndu álag og hraða í starfi en töldu pað ekki endilega galla við starfið sjálft heldur tengdist pað reynsluleysi peirra sjálfra. Stærsti gallinn sem peir nefndu sneri einna helst að pví sem hægt væri að flokka sem undirfjármögnun skólakerfisins en viðmælendur töldu pað eiga við um flest skólastig. Egill nefndi mikinn fjölda nemenda í einum bekk sem yki álag á kennarann og að stuðningsfulltrúar væru fáir eða ynnu ekki allan daginn. Einnig nefndu viðmælendur, í léttu gríni, að pað væri líka galli að pað væru ekki fleiri klukkustundir í sólarhringnum til að ná að sinna öllu fullkomlega (viðtal I.3). Prátt fyrir álag voru viðmælendurnir ákafir í pví að halda áfram að læra á starfið. Hlutir sem höfðu gengið vel gáfu aukið sjálfstraust og atriði sem hefðu mátt ganga betur voru strax komin á teikniborðið til að bæta.

Við lok fyrsta kennsluárs voru allir fjórir viðmælendurnir byrjaðir að hugsa um næsta kennsluár, hvað peir ætluðu að gera og hverju peir vildu breyta. Spennan yfir pví að halda áfram að próa sig í starfi var mikil. Gunnar taldi pað taka tvö til prjú ár að koma sér upp einhvers konar reynslubanka en fannst mikilvægt að vera alltaf að próa pennan hugmyndabanka til að staðna ekki (viðtal I.1). Бó að allir viðmælendur hefðu upplifað eitthvað erfitt hafði enginn fengið pá tilfinningu að geta ekki sinnt pessu starfi. Draga má orð peirra saman í orðum Nóa:

Ég á svo margt eftir ólært að pað er ekki fyndið og pað er bara æðislegt. Ég alveg veit pað að petta er eilífðarverkefni og maður er alltaf að vaxa í starfi, maður getur í raun og veru vaxið í pað óendanlega sko. (Nói viðtal I.1) 


\section{Leiðsögnin}

Degar viðmælendur voru spurðir út í pá leiðsögn og pann stuðning sem peir höfðu fengið í starfinu á fyrstu mánuðunum kom í ljós að peim fannst leiðsögnin minni en peir höfðu búist við. Enginn fékk formlegan leiðsagnarkennara, sem leiðbeindi peim á skipulegan hátt. Öllum var bent á að spyrja ef pað væri eitthvað sem peir vildu vita og peir höfðu ákveðinn aðila, yfirleitt stjórnanda, sem peir gátu leitað til ef eitthvað var. Pá pótti vanta skýrari ramma um leiðsögnina:

Degar pú kemur parna nýr inn pá átti ég kannski meiri von á að pað yrði haldið aðeins meira í höndina á mér og kannski eftir á að hyggja er pað betra að svo sé ekki en ég hefði viljað svona heildstæðari, hvað á ég að segja, umönnun. (Egill, viðtal I.1)

Á vissu tímabili fannst Agli hann hafa of frjálsar hendur, pótt honum pætti traustið gott. Hann sá kosti og galla við petta frelsi en var sannfærður um að með pví að vera kastað út í djúpu laugina hefði hann strax tekist á við pau verkefni sem biðu hans (viðtal I.3). Nói var sammála Agli að pví leyti að frelsið væri mikið. Hann taldi sig pó hafa góðan aðgang að reynslumiklum kennurum og stjórnendum, sem honum fannst gott að geta leitað til og spjallað við.

Prátt fyrir að dyr stjórnenda stæðu opnar voru viðmælendur pó með hugmynd að útfærslu á leiðsögn nýliða, sem hægt væri að styðjast við, nokkurs konar félagakerfi:

Reynslumikill kennari myndi vera svona stuðningskennari, pó að pað væri ekki nema bara fyrri önnina eða hálft skólaárið ... passa að setja ekki hvaða kennara saman, pað purfa að vera persónuleikar sem passa pví annars hættir pessi nýi kennari ef pú ert með einhverja sem passa illa saman. (Nói, viðtal I.3)

Kerfið myndi verða útfært pannig að nýjum kennurum væri úthlutaður reyndari kennari, sem hægt væri að leita til eða hitta og ræða saman. एótt pað sé gott að geta leitað til stjórnenda eru kennarar sem vinna með nemendum alla daga eflaust líklegri til að gefa nýliðum betri svör:

Svo myndi ég vilja hafa pað pannig að væri á tveggja vikna fresti fundur með nýjum kennurum og ég myndi bara vilja hafa pað pannig að peir kennarar sem eru búnir að kenna á fyrsta eða öđru ári, kannski ekki tveggja vikna frekar einu sinni í mánuði pá væri fundur með öllum peim kennurum og stjórnendum, par sem væri farið yfir hvað gengur vel, hvað gengur illa og hvað má gera betur pví pað eru allir að vinna að sama markmiðinu. (Egill, viðtal I.1)

Gunnar taldi að pess háttar kerfi gæti gagnast nýjum kennurum vel, pótt hann hefði verið sáttur með pað utanumhald og frelsi sem hann fékk. Að hans mati var pað gott að hafa frelsi til að „,prófa margt nýtt" en á sama tíma góð tilfinning að vita af peim möguleika að hafa stuðning á bak við sig (Gunnar, viðtal I.2). Sveigjanlegur rammi, líkt og sú leiðsögn sem Gunnar fékk, byði nýjum kennurum upp á pann möguleika að reyna sig við ólíka kennsluhætti, gera mistök og læra af peim og próa kennslu sína áfram. Dó að félagakerfið byði upp á samtöl við reyndari kennara sá Gunnar möguleika á að vaxa í starfi með pví að fara út fyrir pægindarammann og prófa nýjar leiðir, líkt og sveigjanlega formið byði upp á.

Séu niðurstöður pessa kafla dregnar saman má sjá að leiðsögnin var ekki eða yfirleitt ekki formleg, og par af leiðandi líklega of lítil. Enginn viðmælendanna hafði fengið sérstakan leiðsagnarkennara til að sinna sér en allir gátu leitað til stjórnendanna.

\section{Kyn kennara}

Viðmælendur voru spurðir hvort peir hefðu fundið fyrir einhverju í starfinu sem tengdist kyni peirra. Í sumum skólum par sem fáir kennslukarlar eru fyrir skapast pær aðstæður að fáir karlar sækja um starfið: 
Баð eru sum börn sem hafa aldrei haft karlkennara ... petta er orðinn náttúrulega bara vítahringur pví pað er erfitt að fá karlmenn inn. (Gunnar, viðtal I.3)

Eflaust getur pessi staða ekki einungis verið letjandi fyrir aðra karla að sækja um kennaranámið, en fámennið skapar líka möguleika fyrir karla í kennarastarfinu, eins og Egill tók fram:

Maður var klárlega í minnihlutahópi en pað var samt eitthvað svona eftirsóknarvert að vera í pessum minnihlutahópi. (Egill, viðtal I.2)

Yfirleitt voru viðmælendur ánægðir með reynsluna af starfinu og starfsumhverfinu. Баð kom hins vegar í ljós að peir virtust tengjast samstarfsfólki sínu á ólíkan hátt. Dannig tengdust peir kennslukonunum vel faglega meðan peir tengdust öðrum kennslukörlum líka og ekki síður félagslega:

Ég held ég verði að segja kennslukörlum ... en samt er svarið kannski tvípætt, mér finnst ég kannski hafa tengst körlum ... vinaböndum en konum frekar á kennaralegum nótum pví mótkennari [p.e. samkennari í árgangi] minn er kona, pannig að augljósa svarið er körlum, en pað er kannski líka á faglegum grundvelli með mótkennara mínum sem er kvenkyns. (Egill, viðtal I.2)

Allir töldu viðmælendur okkar sig ná að tengjast samkennurum sínum vel og stundum héldu peir pví fram að kyn kennarans skipti engu máli. Engu að síður kom í ljós í svörum viðmælenda að peir virtust tengjast samkennurum sínum ólíkt eftir kyni. Pannig virtist sem peir ættu auðveldara að ræða hluti sem snúa að áhugamálum og atriðum sem tengjast ekki kennslu við aðra kennslukarla frekar en konur. Nói vék að ólíku umræðuefni kennara á kaffistofunni og tók dæmi um að karlar töluðu meira um ípróttir og stjórnmál meðan konurnar töluðu meira um börnin sín (viðtal I.2).

Í premur af peim fjórum skólum, par sem viðmælendurnir störfuðu, voru starfandi sérstakir karlaklúbbar. Í peim skólum hittust karlarnir á sérstökum stað í skólanum eða utan skólatíma, par sem peir spjölluðu eða borðuðu saman. Markmiðið var að efla félagslegan pátt starfsins og töldu peir viðmælendur sem tilheyrðu slíkum klúbbi samveruna vera mikilvæga, sérstaklega fyrir pær sakir að peir tilheyrðu minnihlutahópi:

Við hittumst mjög oft hérna og borðum parna, algjörlega geggjað að geta bara sest niður og rætt um eitthvað annað en barneignir og nemendur og kjaftæði, og við forðumst pað mjög mikið, við ræðum eitthvað annað, fótbolta eða eitthvað ... En málið er að petta er rosalega mikilvægt, petta er bara bráðnauðsynlegt að karlar, eða ekkert endilega karlar, bara að maður hafi eitthvað svona pínu athvarf, petta að vera minnihlutahópur, pað er líka styrkur í pví. (Viktor, viðtal I.2)

Pannig virtust pessir karlaklúbbar vera svar kennslukarlanna við peirri minnihlutastöðu sem peir erúi.

Kynjahlutfall er misjafnt eftir skólum en viðmælendur voru yfirleitt ekki að velta pví fyrir sér pegar peir sóttu um starf að lokinni brautskráningu. Egill var hins vegar í peirri stöðu að geta valið úr skólum og par hafði kynjahlutfallið tvímælalaust áhrif:

Alveg tvímælalaust, ég hugsaði um pað pegar ég stóð frammi fyrir pví að velja pví ég gat í raun og veru valið mér skóla, var svo heppinn að ég gat valið mér par sem pað var nóg af stöðum í boði ... ég horfði alveg í pað ... ekki að pað sé eitthvað slæmt að vinna með konum, alls ekki, en maður vill kannski hafa ... jafnvægi í pví sem er auðvitað leiðinlegt kviksyndi fyrir pá skóla sem eru með fáa nú pegar og pá erfitt að fjölga í peim en ég allavega horfði í pað. (Egill, viðtal I.1) 
Degar viðmælendur voru spurðir beint út í hvort peir hefðu upplifað pað að tilheyra minnihlutahópi í starfi sökum kyns síns voru nefnd bæði jákvæð og neikvæð dæmi. Drír nefndu skýr dæmi sem аð peirra mati tengdist kyni. Viktor taldi að hann væri settur í verkefni „bara“ vegna pess að hann væri karl, til dæmis til að kenna bekkjum sem pættu erfiðir:

Ég hef engan áhuga á pví, bara mjög takmarkaðan pví pau eru ópekk ... en pau [skólastjórnendur] segja bara út af pví pú ert karl pá verður pú að vera par ... ég er búinn að fá petta svar milljón sinnum, „en pú nærð alltaf svo vel til peirra erfiðu.“ (Viktor, viðtal I.2)

Nói upplifði pað einnig að vera karl í miklum minnihluta. Í náminu var hann alltaf umkringdur konum og pegar hann útskrifaðist tók vettvangurinn við með fáum körlum. Hann hafði stundum á tilfinningunni að pað væri tiplað meira á tánum í kringum hann aðeins vegna pess að hann væri karl. Hann taldi sig vita um dæmi par sem skólastjórnendur gæfu körlum ,afslátt“ eða settu pá í pægilegri stöðu en aðra kennara par sem peir vildu halda í pá. Pannig fannst honum hann hafa til dæmis sloppið við að taka ákveðin atriði í samskiptum við foreldra, og túlkaði pað pannig:

Manni hefur ábyggilega verið svolítið hlíft yfir pví af pví maður er nýr ... ég held að ég sé heppinn að ég sé karlmaður ... pað vill enginn missa karlmann úr skólanum. (Nói, viðtal I.1)

Egill sagði, líkt og Viktor og Nói, að hann fyndi fyrir pví að hann tilheyrði minnihlutahópi. Hann taldi pað hins vegar ekki neikvætt. Pegar hann byrjaði að kenna heyrðist úr foreldrahópnum að pað væri frábært að pað væri karl að kenna bekknum. Раð væri eins og pað væri hreinlega verið að leita að honum í starfið:

Maður var að fara í vettvangsnám eða hitta kennara einhvers staðar, [pá var sagt] já pað vantar fleiri karla. Dannig maður var klárlega í minnihlutahópi en pað var samt eitthvað svona eftirsóknarvert að vera í pessum minnihlutahópi. (Egill, viðtal I.2)

Viðmælendur voru spurðir um aðsókn í starfið og rauði práðurinn í svörum peirra sneri að launum kennara. Allir töldu peir launin stærsta páttinn í pví að fleiri karlar sæktust ekki eftir starfi grunnskólakennara:

Launin eru ekki nógu góð ... ég er alveg viss að ef pú tækir aðra svona rannsókn pá eru svona $90 \%$ af körlum, sem eru að kenna, í annarri vinnu með. (Viktor, viðtal I.3)

Viðmælendur okkar fjórir höfðu pó ekki látið launin fæla sig frá starfinu, og eins og sjá má af svörum peirra finna peir fyrir pví að sóst sé eftir peirra starfskröftum.

\section{Umræða og ályktanir}

Í upphafi var spurt hvernig nýbrautskráðum körlum gengi á vettvangi starfsins og hvort peir pyrftu sérhæfðan stuðning í starfinu á grundvelli kyns. Viðmælendurnir fjórir virtust upplifa fyrstu mánuði sína á vettvangi á svipaðan hátt. Áskoranir sem peir stóðu frammi fyrir voru allar eitthvað sem mætti kalla eðlilegt upphaf að lokinni útskrift en allir voru peir mjög ákafir $i ́$ að halda áfram að læra á starfið. Deir fengu frjálsar hendur til að takast á við dagleg verkefni, voru duglegir að reyna nýja hluti og opnir fyrir umhverfi sínu en aðstoð var aldrei langt undan. Reynsla peirra virðist vera í samræmi við niðurstöður fyrri rannsókna (María Steingrímsdóttir 2007; Lilja M. Jónsdóttir 2012a).

Upplifun viðmælenda var að samskipti við nemendur og kennslan væru auðveldustu pættir starfsins, og er líklegt að peir hafi pekkt pá pætti best úr vettvangshluta kennaranámsins. Eftir fimm ára kennaranám hafa peir fengið góðan undirbúning í kennslu og samskiptin við nemendur eru dagleg æfing. Pau atriði sem peim fundust erfiðust eða komu á óvart voru hlutir sem peir 
voru ekki eins vanir, svo sem samskiptin við foreldra. Í rannsókn sem Ragnhildur Bjarnadóttir (2005) gerði spurði hún 72 kennaranema á fyrsta ári hvaða pættir hefðu valdið peim mestu álagi og kvíða og voru foreldrasamskiptin ofarlega á blaði. Aðrar rannsóknir sýna einnig að petta sé sá páttur sem flestir nýir kennarar kvíða mest fyrir (Estola o.fl., 2012). Allir viðmælendur fundu pó fyrir miklum létti pegar búið var að brjóta ísinn.

Móttaka nýliða er mikilvægt viðfangsefni og getur ráđið úrslitum hvernig nýir kennarar upplifa fyrstu skref sín í starfi. Óvissa er eðlileg tilfinning hjá nýjum starfsmönnum og pá er gott að geta haft einhvern að leita til og sem fylgist með pví hvernig pér gengur, bæði á peim tímum pegar gengur vel og pegar gengur síður vel. Pótt nýir grunnskólakennarar nú á dögum séu með fimm ára nám að baki vantar pá reynslu. María Steingrímsdóttir (2007) benti á að skólakerfið pyrfti að viðurkenna раð аð kennaranemar koma ekki fullnuma úr námi sínu og pví pyrfti móttaka og leiðsögn að vera markvissari en hefði verið. Dess vegna er mikilvægt að sinna leiðsögn nýrra kennara á sínum fyrstu árum í kennslu par sem peir eru enn að læra. Viðmælendum okkar virðist pó hafa gengið nógu vel í starfinu, bæði í kennslustofunum og félagslega, til að skortur á formlegri leiðsögn kæmi ekki að sök. Deir hefðu pó allir fagnað formlegri leiðsögn og töldu að peir hefðu purft að hafa formlegt samband við reynslumikinn kennara, mentor, sem peir kölluðu gjarna ,félaga“.

Баð аð nýjum kennurum skuli vera úthlutað reyndari kennara býr til formlega leið par sem nýliðinn fær ráðleggingar og stuðning en sá sem reyndari er græðir einnig á pessari samvinnu, meðal annars með pví að læra af nýliðanum og efla eigin starfskenningu (Hargreaves og Fullan, 2000; Le Cornu, 2005). Estola og félagar (2012) ræddu petta atriði, að pað að fá tækifæri til að deila eigin upplifun eða heyra upplifun annarra í sömu stöðu getur gefið nýútskrifuðum kennara mikið, pví frásögn eins getur orðið öðrum hvatning. Samræður við aðra kennara gefa nýjum kennurum tækifæri til að spegla sjálfa sig og opna á nýjar leiðir eða hugmyndir. Pannig gætu fundir með reynslumeiri og nýjum kennurum skilað sér og ef miðað er við rannsókn Maríu Steingrímsdóttur og Guðmundar Engilbertssonar (2018) er æskilegt að viðkomandi leiðsagnarkennari hafi bakgrunn í sömu kennslugrein og nýliðinn. Við petta má svo bæta að skipulegir fundir eru ef til vill fyrst og fremst liður í pví að skapa grundvöll til ígrundunar til að allir nýliðar njóti leiðsagnar sem felur í sér uppbyggilega gagnrýni, hvort sem peim gengur vel eða eitthvað bjátar á (sbr. Jensen o.fl., 2012).

Öllum viðmælendunum fannst pátttakan í rannsókninni hafa haft góð áhrif á sig pegar peir stigu sín fyrstu skref í kennslu enda fengu peir tækifæri til að ígrunda og ræða reynslu sína við rannsakandann. Viðlíka rannsóknir hafa sýnt sömu niðurstöður, til dæmis rannsókn Lilju M. Jónsdóttur (2012b) og Maríu Steingrímsdóttur (2007), pað er að pátttakendum fannst viðtölin vera sér gagnleg ígrundun.

Af peim premur viðmælendum sem höfðu upplifað eitthvað tengt kyni sínu var reynslan nokkuð ólík. Meðan einn viðmælandi taldi að kyn hans hefði skipt máli pegar erfið verkefni voru annars vegar, par sem talið var henta að kennslukarl stýrði, pá upplifði annar sig sem eftirsóknarverðan einstakling vegna pess að hann tilheyrði kyni sem væri í miklum minnihluta. Viktor kom með skýrt dæmi úr sínu starfi sem sýndi eðlishyggju par sem hann var settur í viss verkefni vegna pess að hann er karl. Dá er búið að ákveða pað, af skólastjórnendum, að hann hafi einhverja eiginleika til að bera út af sínu líffræðilega kyni, sem ráđi pví hvað hann gerir og af hverju (Ingólfur Ásgeir Jóhannesson, 2004). Eitt af pví sem Sargent (2001) komst að í rannsókn sinni var meðal annars að kennslukarlar héldu hópinn vegna pess að peir nenntu ekki að hlusta á umræður um málefni kvenna. Í pví sambandi má velta fyrir sér hvort eðlishyggjan skipti áhugamálum kynjanna í flokka, líkt og Nói taldi upp.

Hugmyndir um að flokka störf í karla- og kvennastörf eru vitanlega ekki í takt við 21. öldina. Dó að annað hvort karlar eða konur starfi í ákveðnum stéttum og séu í miklum meirihluta par, pá gerir pað starfið ekki að eðlislæegu karla- eða kvennastarfi. Hugmyndin um karla- og 
kvennastörf viðheldur kenningum um að hæfni kynjanna sé ólík. Detta kemur vel í ljós í pví sem viðmælendur sögðu, að peir væru tilbúnir að sinna öllum hliðum starfsins en peim fannst ósanngjarnt pegar peim voru falin viss verkefni, eða pegar peir nutu sérréttinda af pví peir voru karlar. Pannig má meðal annars nefna reynslu Viktors, sem var settur yfir erfiðan hóp par sem einu rökin voru pau að hann væri karl.

Laun eru sérstakur kapítuli í umræðu um kennarastarfið, og svo var einnig í pessari rannsókn. Allir viðmælendur töldu launin stærsta páttinn í pví að fleiri karlar sæktust ekki eftir starfi grunnskólakennara. Sama kom fram í viðtölum Ingólfs Ásgeirs Jóhannessonar (2004) við 14 kennslukonur um síðustu aldamót; pær voru á einu máli um að launin fældu karla frá starfinu. Skýringin gæti verið sú að laun í samfélaginu eru yfirleitt pannig uppsett að karlar fá að jafnaði talsvert hærri laun en konur - karlar sem fara úr starfinu eiga auðveldara en konurnar að fá betur borguð störf pví að vitanlega fá kennslukarlar og kennslukonur sömu grunnlaun.

Ef til vill kom á óvart hversu lítið viðmælendur gerðu úr reynslunni af pví að vera í minnihluta. Dað kom aftur á móti ekki á óvart að sú reynsla væri mestmegnis jákvæð enda virtust peir eftirsóttir. Einnig kom á óvart aðgreiningin milli faglegs samstarfs og félagslega páttarins, að pótt faglegt samstarf hefði ekki farið eftir kyni pá voru vísbendingar um félagslega aðgreiningu, bæði í formi karlaklúbba og daglegra samskipta.

\section{Samantekt og lokaorð}

Í upphafi greinar var spurt hvernig nýbrautskráðum kennslukörlum hefði gengið á vettvangi starfsins og hvort peir pyrftu sérhæfðan stuðning í starfinu á grundvelli kyns síns.

Líkt og kemur fram í niðurstöðunum voru viðmælendurnir enn að læra prátt fyrir að hafa lokið fimm ára kennaranámi. Svarið við fyrri hluta spurningarinnar er pví einfalt: Viðmælendur okkar töldu að sér hefði gengið vel en meiri og betri leiðsögn væri af hinu góða. Deir vita í reynd ekki hvort eða hvaða máli pað hefði skipt að fá formlegri leiðsögn en peir fengu. Fyrri rannsóknir benda pó til pess að blandaðar aðferðir við að greiða fyrir aðlögun nýliða að starfsvettvanginum, ekki síst formleg leiðsögn reynds kennara í sömu grein og sameiginlegur skipulagstími með honum, skipti miklu máli (sjá til dæmis Ingersoll, 2012). Leiðsögnin parf pví að minnsta kosti að lúta að faglegum páttum starfsins.

Við spurðum okkur líka að pví hvort karlar pyrftu sérhæfðan stuðning í starfinu. Slík spurning er sett fram með рað í huga að halda utan um pá fáu karla sem sækjast eftir kennarastarfinu og með pað fyrir augum að peir hverfi ekki á braut. Í pessum stuðningi gæti falist að ákveðnir skólar tækju sig saman til að skapa félagslegan vettvang eða stuðningsnet fyrir nýbrautskráða karla til аð hittast og spjalla um fyrstu upplifun sína af kennslu, og nýttu pannig reynslu af karlaklúbbum innan margra skóla. Helgi Eiríkur Eyjólfsson (2017) hefur reiknað út að hlutfallslega fleiri karlar, sem á annað borð hefja störf sem grunnskólakennarar, hverfi frá starfinu en konur. Á sama hátt getur verið eðlilegt að leiðsögn við nýbrautskráðar kennslukonur sé á einhvern hátt sérstök, pví gæti verið ástæða til að prófa hvort tveggja og a.m.k. að nýta sér karlaklúbba og önnur stuðningsnet sem kunna að vera fyrir hendi.

Svarið við spurningunni hvort pað purfi sérhæfðan stuðning eftir kyni er ekki einhlítt. Reyndar voru viðmælendur okkar ánægðir prátt fyrir að leiðsögnin væri ekki sérlega formleg. Ekki er gott að segja hvernig á að túlka pað; e.t.v. er pað vísbending um hversu alvarlega parf að taka pað verkefni að koma á formlegri og markvissri leiðsögn, til dæmis með pví að mennta fleiri sérhæfða kennara til að starfa við leiðsögnina. Mögulega var sú athygli sem peir fengu sem karlar, og sem pátttakendur í rannsóknarverkefni, fullnægjandi til að vinna á móti pví hversu lítil formlega leiðsögnin var. Í rannsókn Maríu Steingrímsdóttur og Guðmundar Engilbertssonar (2018) kom fram að kennslukarlar í grunn- og framhaldsskólum höfðu sjaldnar hitt leiðsagnarkennara sína en kennslukonurnar. Varhugavert hlýtur pó að vera að draga af pessu pá ályktun að nýbrautskráðir 
karlar hljóti að jafnaði lakari leiðsögn en nýbrautskráðar konur. Óhætt er pó að undirstrika að ef skólar og samfélag vilja fleiri karla í grunnskólakennslu verður að veita peim, ekki síður en nýbrautskráðum konum, bestu fáanlegu leiðsögn og stuðning í starfinu, bæði faglega leiðsögn og félagslegan stuðning.

Hvað varðar sértækar endurbætur teljum við sjálfsagt að athuga hvort kynskiptir klúbbar gagnist sem ein af leiðunum til pess að nýliðar haldist vel í starfinu. Cushman (2007) leggur einmitt til að karlarnir ræði saman um reynslu sína sem minnihlutahópur í kerfinu. Cushman bendir einnig á að eldri kennslukarlar gætu tekið að sér að vera leiðsagnarkennarar fyrir nýja kennslukarla. Mikilvægi markvissrar leiðsagnar fyrir nýliða í starfi er pó ekki kynbundið atriði heldur verður að leggja áherslu á að allir nýir kennarar, óháð kyni, fái góða leiðsögn og gott utanumhald pegar peir stíga sín fyrstu skref í starfi. Kynskiptir klúbbar og kynjaskipt leiðsögn væru pá einungis hluti af heildstæðu og vönduðu kerfi nýliðapjálfunar.

Dessi rannsókn er fyrsta íslenska rannsóknin sem sérstaklega beinist að starfi íslenskra kennslukarla 1 grunnskólum. Höfundarnir vona að niðurstöður hennar séu nægilega hvetjandi fyrir unga karla og verði ekki til pess að peir forðist kennarastarfið heldur vilji hefja kennaranám - annað hvort að loknu stúdentsprófi eða fara í tveggja ára nám að loknu bakkalárprófi. Einungis pannig er líklegt að snúið verði við peirri próun sem McGrath og Van Bergen (2017) vísa til, pað er að kennslukörlum fækki hlutfallslega í yngri bekkjum skyldunámsskóla. Pað er samt ekki nóg að vera karl til að verða eftirsóknarverður kennari heldur purfa ungu karlarnir, eða peir sem fara í kennaranám á fertugs- eða fimmtugsaldri, leiðsögn frá reyndara samstarfsfólki, bæði körlum og konum. Rökræða um hættuna að karlar verði „,útdauða“ í starfinu („Eru karlar“, 2015) er tæpast árangursrík stjórnlist til að laða karlana að. Spurningunni um hvort karlar í grunnskólakennslu - eða annarri kennslu - séu eftirsóttasti minnihlutahópurinn er pó ekki hægt að svara í peim skilningi. Deir eru minnihluti í grunnskólakennslu pegar litið er til talnanna - en peir eru ekki valdalítill minnihluti.

Við viljum hvetja til frekari rannsókna á kennarastarfinu og nýliðun í pað, bæði almennt og á grundvelli kyngervis. Mögulega væri hægt að framkvæma rannsókn svipaða og pessa og hafa fleiri viðmælendur sem væri fylgt eftir á sínum fyrstu skrefum í kennslu. Einnig væri hægt að fylgja nýbrautskráđum kennslukörlum lengur eftir í starfinu og fylgja eftir ungum kennslukonum par sem rædd væri markvisst reynsla á grundvelli kynjasjónarmiða.

\section{Aftanmálsgreinar}

1. Greinin er byggð á meistaraprófsrannsókninni Eftirsóttasti minnihlutahópurinn? Fyrstu mánuðir kennslukarla í starfi [tilvísun verður sett inn eftir rýni]. Rannsóknin naut styrks úr Rannsóknasjóði Háskóla Íslands. Höfundar pakka viðmælendum fyrir pátttökuna og Maríu Steingrímsdóttur og Sunnu K. Símonardóttur fyrir yfirlestur og ábendingar.

2. Athugunin var gerð í október 2018. Safnskólarnir prír eru Garðaskóli, Hagaskóli og Réttarholtsskóli og skólarnir sem kenna yngri börnum eru Flataskóli, Hofsstaðaskóli, Grandaskóli, Melaskóli,Vesturbæjarskóli, Breiðagerðisskóli og Fossvogsskóli.

3. Tímasetning síðasta viðtalsins miðaðist við að ljúka bví eins seint á skólaárinu sem kostur væri en tækist pó að ljúka meistaraprófsverkefninu vorið 2018, svo að fyrri höfundurinn gæti hafið störf sem grunnskólakennari.Viðtölin eru merkt I.1, I.2 og I.3 til aðgreiningar frá viðtölum við annan hóp pátttakenda í framhaldsrannsókn sem hefur hlotið styrk úr Jafnréttissjóði Íslands. 


\section{The most sought-after minority group? The first months of four newly- graduated male teachers}

The possible shortage of teachers at compulsory school level in Iceland, and the decreasing proportion of male teachers at the same school level has been discussed in recent years. These discussions, especially on the status of male teachers, have sparked our interest in performing this study. This is also an international debate concerning the notion that male teachers might become "extinct" at primary level (e.g., McGrath and Van Bergen, 2017).

The background of the study constitutes two often separate bodies of research. On the one hand research on novices in teaching and, on the other, studies focusing on male teachers. The article reports a study where we interviewed four newly-graduated male teachers three times during their first six months: First in August 2017 before teaching commenced, then in late October or November the same year, and, lastly, at the end of January or in early February 2018. They taught in four schools in different parts of the country. We asked them how they felt they were doing in their practice and whether they had experienced anything that could be related to their gender. Our main research question was twofold: How do newly-graduated male teachers adjust to their new field of practice, and do they need specific support measures because of their gender?

In the article, we report three prominent themes in the interview data: Firstly, the experience of the new field of practice and the working environment. The interviewees emphasized that they had not encountered any serious obstacles and were pleased with the work, although they did at times have long working hours under some amount of stress. They said it had been rather easy to get to know the students; however, parent cooperation was the area they were most insecure about, especially in the beginning.

The second theme is the novice male teachers' experience of the mentoring and supervision they received. None of them had a specially assigned mentor, apart from school administration members, but all had been told that they could ask if they needed something. They said they would have preferred a formal structure around the mentoring as recommended in the theoretical and research literature.

And thirdly, whether and how gender appeared in their discussion. One of the themes concerns separation between the professional and social in such a way they reported good professional relationships with both women and men teachers - but said they had in general stronger social relationships with the other men teachers, for instance in the male-only "clubs" that functioned in three of the four schools where our interviewees taught, clubs that had lunches together one day in the week or had other social agenda.

To sum up and return to the research questions, the newly-graduated male teachers said they had adjusted well to their new field of practice. The answer to the second part of the question - whether they need specific support measures because of their gender - is not a consistent because they felt sought-after, but they also felt, at times, that they were a minority. The male-only groups are of special interest; they argued that these had been important in adjusting to the school culture. This may merit further research as to whether such arrangements are feasible to keep novice male teachers on the job. 
We suggest further exploring whether gender-divided groups can assist in the task of supporting novices so they keep teaching rather than leaving the job. However, the importance of well-organized supervision and mentoring of novices must not be underestimated, and all new teachers, irrespective of gender, need quality supervision in their first steps of teaching. Gendered supervision and, in particular, genderdivided support and study groups would, then, only be one aspect of a holistic and state-of-the-art system of novice training.

Key words: Male teachers, mentoring, teachers' gender, novice teachers.

\title{
Um höfundana
}

Andri Rafn Ottesen (andriot@gardaskoli.is) er grunnskólakennari við Garðaskóla. Hann lauk B.Ed.-gráðu í grunnskólakennarafræði vorið 2016 frá Menntavísindasviði Háskóla Íslands og M.Ed.-gráðu vorið 2018 frá sama skóla. Hann hefur brennandi áhuga á stöðu karla í kennslu og leiðsögn við nýliða og hefur beitt sér fyrir framgangi hugmynda um kandidatsár fyrir nýbrautskráda kennara.

Ingólfur Ásgeir Jóhannesson (ingo@hi.is) er prófessor við Menntavísindasvið Háskóla Íslands. Hann lauk BA- og cand.mag.-prófi í sagnfræði frá Háskóla Íslands. Hann lauk einnig doktorsprófi í menntunarfræðum frá Wisconsin-háskóla í Madison. Hann hefur sérhæft sig í rannsóknum á menntastefnu, kennarastarfinu og kyngervi og menntun.

\begin{abstract}
About the authors
Andri Rafn Ottesen (andriot@gardaskoli.is) is a lower secondary school teacher at Garðaskóli. He completed a B.Ed. degree in compulsory school teaching in 2016 from the School of Education at the University of Iceland and an M.Ed. degree in 2018 from same school. His areas of special interest are the status of men in teaching and guidance for newcomers. He has advocated the implementation of an induction year for newly qualified teachers.

Ingólfur Ásgeir Jóhannesson (ingo@hi.is) is a professor at the School of Education at the University of Iceland. He holds BA and cand.mag. degrees in history from the University of Iceland. He also holds a Ph.D. in curriculum and instruction from the University of Wisconsin, Madison. His research focuses on education policy, teacher expertise, and gender and education.
\end{abstract}




\section{Heimildir}

Berliner, D. C. (1992). The nature of expertise in teaching. Í F. K. Oser, A. Dick og J.-L. Patry (ritstjórar), Effective and responsible teaching: The new synthesis (bls. 227-248). San Francisco: Jossey-Bass.

Bhana, D. og Moosa, S. (2016). Failing to attract males in foundation phase teaching: An issue of masculinities. Gender and Education, 28(1), 1-19. doi:10.1080/09540253.2015.1105934

Connell, R. og Messerschmidt, J. (2005). Hegemonic masculinity: Rethinking the concept. Gender \& Society, 19(6), 829-859. doi:10.1177/0891243205278639

Cushman, P. (2005). Let's hear it from the males: Issues facing male primary school teachers. Teaching and Teacher Education, 21(3), 227-240.

Cushman, P. (2007). The male teacher shortage: A synthesis of research and worldwide strategies for addressing the shortage. Kedi Journal of Educational Policy, 4(1), 7-98.

Eru karlar í kennarastétt að deyja út? (2015, 1. september). Skólavarðan, bls. 8.

Estola, E., Syrjälä, L. og Maunu,T. (2012). The first years as a teacher. Í H. Heikkinen, H. Jokinen og P.Tynjälä (ritstjórar), Peer-group mentoring for teacher development (bls. 43-51). London \& New York: Routledge.

Francis, B. (2008). Teaching manfully? Exploring gendered subjectivities and power via analysis of men teachers' gender performance. Gender and Education, 20(2), 109-122. doi:10.1080/09540250701797226

Hagstofa Íslands. (e.d.-a). Starfsfólk við kennslu eftir kyni, landsvæðum og kennsluréttindum 1998-2017. Sótt af https:// www.hagstofa.is/talnaefni/samfelag/menntun/grunnskolastig/

Hagstofa Íslands. (e.d.-b). Starfsfólk eftir kyni, starfsheiti, tegund og aðsetri skóla 1999-2012. Sótt af https://hagstofa.is/ talnaefni/samfelag/menntun/framhaldsskolastig/

Hagstofa Íslands. (e.d.-c). Starfsfólk í leikskólum eftir kyni, starfssviðum og rekstraraðilum 1998-2016. Sótt af https:// www.hagstofa.is/talnaefni/samfelag/menntun/leikskolastig/

Hagstofa Íslands. (2018). Kennurum án kennsluréttinda fjölgar í grunnskólum. Sótt af https://www.hagstofa.is/utgafur/ frettasafn/menntun/grunnskolar-haustid-2017/

Hammerness, K., Darling-Hammond, L. og Brandsford, J. (2005). How teachers learn and develop. Í L. Darling-Hammond og J. Brandsford (ritstjórar), Preparing teachers for a changing world: What teachers should learn and be able to do (bls. 358-389). San Francisco: Jossey-Bass.

Hargreaves, A. og Fullan, M. (2000). Mentoring in the new millennium. Theory into Practice, 39(1), 50-56. doi:10.1207/ s15430421tip3901_8

Helgi Eiríkur Eyjólfsson. (2017). Tímaatburðagreining á ferli nýútskrifađra grunnskólakennara (meistaraprófsritgerð). Háskóli Íslands, Félags- og mannvísindadeild, Reykjavík.

Hjalmarsson, M. og Löfdahl, A. (2014). Being caring and disciplinary - male primary school teachers on expectations from others. Gender and Education, 26(3), 280-292. doi:10.1080/09540253.2014.901731

Hoy, A.W. og Spero, R. B. (2005). Changes in teacher efficacy during the early years of teaching: A comparison of four measures. Teaching and Teacher Education, 21(4), 343-356. doi:10.1016/j.tate.2005.01.007

Ingersoll, R. (2012). Beginning teacher induction: What the data tell us. Phi Delta Kappan, 93(8), 47-57.

Ingólfur Ásgeir Jóhannesson. (2004). Karlmennska og jafnréttisuppeldi. Reykjavík: Rannsóknarstofa í kvenna- og kynjafræðum.

Jensen, B., Sandoval-Hernández, A., Knoll, S. og Gonzales, E. J. (2012). The experience of new teachers. Results from TALIS 2008. París: OECD.

Le Cornu, R. (2005). Peer mentoring: Engaging pre-service teachers in mentoring one another. Mentoring and Tutoring, 13(3), 355-366. doi:10.1080/13611260500105592

Lilja M. Jónsdóttir. (2012a). „Рað er náttúrulega ekki hægt að kenna manni allt“:Viðhorf byrjenda í grunnskólakennslu til kennaranáms síns. Netla - Veftímarit um uppeldi og menntun. Sótt af http://netla.hi.is/greinar/2012/ryn/005.pdf

Lilja M. Jónsdóttir. (2012b). Hitching one's wagon to a star. Narrative inquiry into the first five years of teaching in Iceland (doktorsritgerð). Háskóli Íslands, Kennaradeild, Reykjavík.

Loftur Guttormsson og Ólöf Garðarsdóttir. (2012). Íslenskir barnakennarar 1930 og 1960: Félagsleg og lýðfræðileg einkenni. Rádstefnurit Netlu - Menntakvika 2012. Sótt af http://netla.hi.is/menntakvika2012/010.pdf

María Steingrímsdóttir. (2007). „, Ofsalega erfitt og rosalega gaman“: Reynsla nýbrautskráðra kennara - aukin vinnugleði. Uppeldi og menntun, 16(2), 9-26.

María Steingrímsdóttir. (2010). „Nú veit maður út á hvað starfið gengur“: Hvað segja kennarar eftir fimm ár í kennslu? Uppeldi og menntun, 19(1-2), 71-90. 
María Steingrímsdóttir, Eygló Björnsdóttir og Gretar L. Marinósson. (2018). Leiðsögn kennara í Byrjendalæsi. Í Rúnar Sigpórsson og Gretar L. Marinósson (ritstjórar), Byrjendalasi. Rannsókn á innleiðingu og aðferð (bls. 305-330). Reykjavík: Háskólinn á Akureyri og Háskólaútgáfan.

María Steingrímsdóttir og Guðmundur Engilbertsson. (2014,15.-16. maí). Stuðningur við núliða í starfi. Erindi á ráđstefnunni Norðan við hrun - sunnan við siðbót, 8. ráđstefnu um íslenska bjóðfélagið. Háskólinn á Hólum.

María Steingrímsdóttir og Guðmundur Engilbertsson. (2018). Mat nýliða á gagnsemi leiðsagnar í starfi kennara. NetlaVeftímarit um uppeldi og menntun. Sótt af http://netla.hi.is/greinar/2018/ryn/03

Maríanna Jónsdóttir Maríudóttir og Ingólfur Ásgeir Jóhannesson. (2018). Kyngervi kennara í augum foreldra: Mótsagnakenndar kröfur. Netla - Veftímarit um uppeldi og menntun. Sótt af http://netla.hi.is/greinar/2018/ryn/06.pdf

Martino, W. J. (2008). Male teachers as role models: Addressing the issues of masculinity, pedagogy and the re-masculinization of schooling. Curriculum Inquiry, 38(2), 189-223. doi:10.1111/j.1467-873X.2007.00405.x

McGrath, K. F. og Van Bergen, P. (2017). Are male teachers headed for extinction? The 50-year decline of male teachers in Australia. Economics of Education Review, 60, 159-167. doi:10.1016/j.econedurev.2017.08.003

Nefnd um efnahagsleg völd kvenna. (2004). Efnahagsleg völd kvenna. Skýrsla. Reykjavík: Forsætisráðuneytið.

Ragnhildur Bjarnadóttir. (2005). Hvernig styður Kennaraháskóli Íslands við starfshæfni kennaranema? Uppeldi og menntun, 14(1), 29-48.

Ragnhildur Bjarnadóttir. (2015). Leiðsögn: Lykill að starfsmenntun og skólapróun. Reykjavík: Háskólaútgáfan.

Sargent, P. (2001). Real men or real teachers? Contradictions in the lives of men elementary school teachers. Harriman: Men's Studies Press.

Stefán Hrafn Jónsson og Helgi Eiríkur Eyjólfsson. (2016).Yfirvofandi fækkun grunnskólakennara næstu áratugi: Lýðfræðileg greining. Í Djóđarspegillinn - Rádstefna í félagsvísindum XVII - Ágripabók (bls. 30). Reykjavík: Félagsvísindastofnun Háskóla Íslands.

Sternberg, R. og Horvath, J. (1995). A prototype view of expert teaching. Educational Researcher, 24(6), 9-17.

Andri Rafn Ottesen og Ingólfur Ásgeir Jóhannesson. (2019).

Eftirsóttasti minnihlutahópurinn? Fyrstu mánuðir fjögurra karla í grunnskólakennslu

Netla - Veftímarit um uppeldi og menntun. Menntavísindasvið Háskóla Íslands.

Sótt af http://netla.hi.is/greinar/2019/ryn/01

DOI: https://doi.org/10.24270/netla.2019.1 